\title{
Seasonal changes in the population structure of dominant planktonic copepods collected using a sediment trap moored in the western Arctic Ocean
}

\author{
Kohei Matsuno $^{\mathrm{a} *}$, Atsushi Yamaguchi ${ }^{\mathrm{b}}$, Amane Fujiwara ${ }^{\mathrm{a}}$, Jonaotaro Onodera ${ }^{\mathrm{c}}$, \\ Eiji Watanabe ${ }^{\mathrm{c}}$, Naomi Harada ${ }^{\mathrm{c}}$ and Takashi Kikuchi ${ }^{\mathrm{c}}$ \\ ${ }^{a}$ Arctic Environment Research Center, National Institute of Polar Research, Tachikawa, Tokyo, \\ Japan; ${ }^{b}$ Laboratory of Marine Biology, Graduate School of Fisheries Science, Hokkaido \\ University, Hakodate, Hokkaido, Japan; 'Japan Agency for Marine-Earth Science and \\ Technology, Yokosuka, Kanagawa, Japan
}

(Received 3 September 2014; accepted 5 February 2015; first published online 29 June 2015)

\begin{abstract}
Winter ice cover of the Arctic Ocean makes year-round zooplankton sampling by plankton net a difficult task. Therefore, the collection of copepods with a sediment trap can be a powerful tool. In the present study, we analysed the seasonal changes in the population structures of five dominant planktonic copepods (Oncaea parila, Calanus hyperboreus, Metridia longa, Paraeuchaeta glacialis and Heterorhabdus norvegicus), which were collected using a sediment trap rotated at 10-15 day intervals moored at $184-260 \mathrm{~m}$ in the Northwind Abyssal Plain $\left(75^{\circ} 00^{\prime} \mathrm{N}, 162^{\circ} 00^{\prime}\right.$ W) of the western Arctic Ocean from October 2010 to September 2012. Oncaea parila $\mathrm{C6F}$ with egg sacs occurred throughout the year, and the total abundance and composition of early copepodid stages $(\mathrm{C} 1-\mathrm{C} 3)$ had two peaks each year. Calanus hyperboreus was dominated by $\mathrm{C6F}$ throughout the year, and their maturation was observed during February to May. Metridia longa C6F had a clear seasonality in lipid accumulation and gonad maturation: high lipid accumulation was observed from October to February, whereas gonad maturation occurred from March to September. Paraeuchaeta glacialis C6F also showed seasonality in lipid accumulation and gonad maturation, although their seasonal patterns varied from those of $M$. longa: high lipid individuals were abundant from February to April and mature individuals dominated from October to November. Heterorhabdus norvegicus showed seasonal changes in population structure as well: $\mathrm{C} 1, \mathrm{C} 5$, and C6M dominated from April to May, November to February and August to October, respectively. The life cycle patterns of these species are compared with those reported from other areas. While the results obtained by a sediment trap are inevitably subject to collection bias (i.e. passive collection at a fixed depth), a sediment trap should be considered as a powerful tool for the evaluation of the life cycle of planktonic copepods, especially in ice-covered oceans.
\end{abstract}

Keywords: copepods; population structure; lipid accumulation; gonad maturation; western Arctic Ocean

\section{Introduction}

In the marine ecosystem of the Arctic Ocean, planktonic copepods are important secondary producers and food sources for fish and marine mammals (Lowry

*Corresponding author. Email: k.matsuno@fish.hokudai.ac.jp 


\section{K. Matsuno et al.}

et al. 2004; Wassmann et al. 2006). Within the planktonic copepods, calanoid copepods are dominant in terms of biomass (Ashjian et al. 2003). The calanoid copepods are dominated by particle-feeders Calanus glacialis, Calanus hyperboreus, and Metridia longa, and various studies have been undertaken on their life cycles (Conover and Huntley 1991; Ashjian et al. 2003; Falk-Petersen et al. 2009). In contrast, little research exists on carnivorous copepods (e.g. Paraeuchaeta spp.) and small poecilostomatoid copepods (e.g. Oncaea spp.) (Heron et al. 1984; Kosobokova et al. 2007).

In the Arctic Ocean, because of ice coverage during winter, year-round zooplankton sampling by plankton nets is difficult. So, researchers have tested semi-quantitative methods for the collection of zooplankton using a sediment trap to estimate the life cycles of planktonic copepods in the Arctic Ocean (Forbes et al. 1992; Willis et al. 2006, 2008; Ota et al. 2008; Sampei et al. 2009; Makabe et al. 2010). Most of these studies evaluated copepod population structure, but few have attempted to assess lipid accumulation or gonad maturation (Hargrave et al. 1989; Ota et al. 2008). Recently, Matsuno et al. (2014) evaluated both lipid accumulation and gonad maturation of several species, but their study lasted only one year and was limited to the sampling of large-sized calanoid copepods (small poecilostomatoid copepods were not included).

In the present study, we evaluated the population structure and reproductive periods of five planktonic copepods, including small poecilostomatoid copepods and two carnivorous copepods, in the Arctic Ocean, based on sediment trap samples collected over the course of two years. Based on these results, we will discuss what factors control the life cycles of these sympatric species.

\section{Materials and methods}

\section{Field sampling}

Samples were collected using a sediment trap (SMD26 S-6000, open mouth area $0.5 \mathrm{~m}^{2}$; Nichiyu Giken Kogyo, Kawagoe, Japan) rotated at 10-15 day intervals moored at a depth of $184-260 \mathrm{~m}$ in the Northwind Abyssal Plain (St. NAPt, $75^{\circ} 00^{\prime}$ $\mathrm{N}, 162^{\circ} 00^{\prime} \mathrm{W}$, bottom depth $1975 \mathrm{~m}$ ) in the western Arctic Ocean from 4 October 2010 to 28 September 2011 (first year) and 4 October 2011 to 18 September 2012 (second year) (Figure 1). The end of the trap rope was anchored to the sea bottom. Before the trap was deployed, 5\% buffered formalin seawater was added to the cups. After the trap was retrieved, the 52 samples were gently filtered with $1 \mathrm{~mm}$ mesh. One-tenth aliquots of the $<1 \mathrm{~mm}$ size fraction were filtered on a weighed polycarbonate membrane filter. The filters were weighed with an analytical balance to calculate the total mass flux (mg dry mass $[\mathrm{DM}] \mathrm{m}^{-2} \mathrm{day}^{-1}$ ).

Detailed description and discussion of the zooplankton collection efficiencies of sediment traps can be found in Matsuno et al. (2014). The moored depth and temperature (with a precision of $\pm 0.2^{\circ} \mathrm{C}$ ) at the mooring depth were monitored every hour. The current speed at St. NAPt was estimated by a physical ocean general circulation model: the Center for Climate System Research Ocean Component Model version 4.9 (Watanabe et al. 2014). Weekly data on the averaged percentage of ice coverage around St. NAPt $\left(74.5^{\circ} \mathrm{N}, 161.5^{\circ} \mathrm{W}\right.$ to $\left.75.5^{\circ} \mathrm{N}, 162.5^{\circ} \mathrm{W}\right)$ during the mooring period were calculated from the sea ice concentration data set (http://iridl.ldeo. 


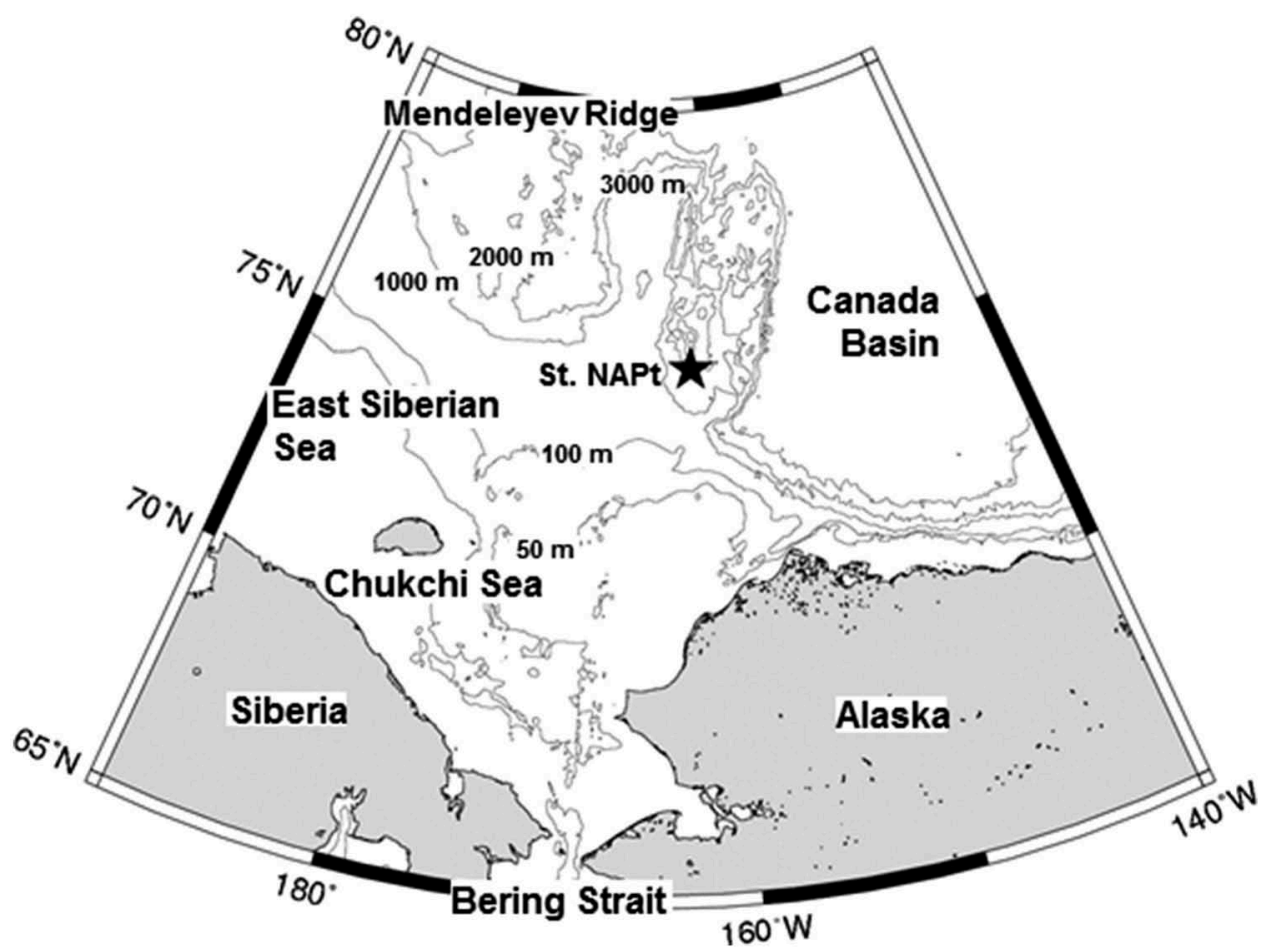

Figure 1. The location of St. NAPt (Northwind Abyssal Plain) in the western Arctic Ocean where the sediment trap was moored at a depth of approximately 184-260 m from October 2010 to September 2012.

columbia.edu/SOURCES/.IGOSS/.nmc/.Reyn_SmithOIv2/, Reynolds et al. 2002). Daily surface chlorophyll $a$ (chl. a) data, measured by MODIS/Aqua at $9 \mathrm{~km}$ resolution, were smoothed using a nine-day running mean.

\section{Analysis of zooplankton community}

In this study, all fractions $>1 \mathrm{~mm}$ and $1 / 10$ of fractions $<1 \mathrm{~mm}$ were used to identify and enumerate the copepods under a dissecting microscope. Species identification of the copepods mainly followed that described by Brodsky (1967) and Heron et al. (1984) for the Oncaea spp., Frost (1974) for the Calanus spp., Miller (1988) for the Neocalanus spp. and Frost (1989) for the Pseudocalanus spp. The identification of five dominant copepods (Oncaea parila, C. hyperboreus, M. longa, Paraeuchaeta glacialis, and Heterorhabdus norvegicus) was made at the copepodid stage level. For adult females C6Fs of the C. hyperboreus, M. longa and P. glacialis, the lipid store and gonad maturation were evaluated. The oil sac volume (OSV) relative to the prosome volume (PV) was ranked into three groups: I (OSV is $0-4 \%$ of the PV), II (OSV is $440 \%$ of the PV) and III (OSV is $>40 \%$ of the PV). The gonad maturation of the $\mathrm{C} 6 \mathrm{~F}$ was also ranked into three groups: I (immature), II (small oocytes in the ovary or oviduct) and III (large eggs or a distended opaque mass in oviduct). For this gonad maturation index, we used the indices proposed for 
C. hyperboreus (Hirche and Niehoff 1996) and M. longa (Tande and Grønvik 1983). Within the large-sized calanoid copepods, neither lipid accumulation nor gonad maturation was measured in $H$. norvegicus due to the method of oil storage (stored as many small oil droplets) and the low transparency of the prosome.

The flux $\left(F\right.$, ind. $\mathrm{m}^{-2}$ day $\left.^{-1}\right)$ of copepods was calculated with the following equation:

$$
F=N \times \frac{1}{0.5} \times \frac{1}{d}
$$

where $N$ is the number of individuals (ind.), 0.5 is mouth area $\left(\mathrm{m}^{2}\right)$ of the sediment trap and $d$ is sampling interval (days). Because there were few differences between the first and second year (same seasonal repetition) ( $p<0.01$, liner regression analysis), the two-year average with a 15 day running mean was used to calculate the abundance, population structure, lipid accumulation, and gonad maturation of each species.

\section{Results}

\section{Environmental conditions}

The trap mooring depth varied between $184-190 \mathrm{~m}$ (first year) and $250-260 \mathrm{~m}$ (second year) but temporarily deepened to approximately $300 \mathrm{~m}$ in July 2012 (Figure 2a). Temperature at the sediment trap ranged from -1.89 to $0.5^{\circ} \mathrm{C}$, and rapid changes in temperature reflected the changes in depth of the moored trap (Figure $2 \mathrm{a}$ and $\mathrm{b}$ ). The current velocity simulated by the ocean circulation model showed a slow current $\left(<2.7 \mathrm{~cm} \mathrm{~s}^{-1}\right.$ at depths of $188 \mathrm{~m}$ and $<1.2 \mathrm{~cm} \mathrm{~s}^{-1}$ at depths of $275 \mathrm{~m}$ ) around the trap (Figure 2c). The sea ice concentration around the sediment trap site showed clear seasonal changes, with a decrease from early July, complete melting (sea ice concentration: $0 \%$ ) in September, a rapid increase during October, and $100 \%$ coverage from November to June (Figure 3a). High chl. $a$ was observed during the open water period (August-September) (Figure 3a). The total mass flux $\left(<1 \mathrm{~mm}\right.$ size range) ranged from 0.1 to $215.9 \mathrm{mg} \mathrm{DM} \mathrm{m}^{-2}$ day $^{-1}$, showed large seasonality, and peaked in November-December in both years (Figure 3a). At St. NAPt, the daylight hours also showed great seasonal changes: polar night was from the middle of November to early February, and the midnight sun occurred from early May to the middle of August (Figure 3b).

\section{Copepod community}

Copepod abundance ranged from 24 to 468 ind. $\mathrm{m}^{-2}$ day ${ }^{-1}$ and was greater from October to November in 2010 and 2011 and from March to June in 2012 (Figure 4). In taxonomic composition, the poecilostomatoid copepod $O$. parila was dominant ( $80 \%$ of the annual mean). The calanoid copepods C. hyperboreus (1\%), M. longa (4\%), P. glacialis (4\%), and H. norvegicus (4\%) were also abundant (Figure 4).

The population structure of each of the five dominant copepods (O. parila, C. hyperboreus, M. longa, P. glacialis, and H. norvegicus) varied. For O. parila, $\mathrm{C} 6 \mathrm{~F}$ with egg sacs occurred throughout the year. Abundance peaked from March 

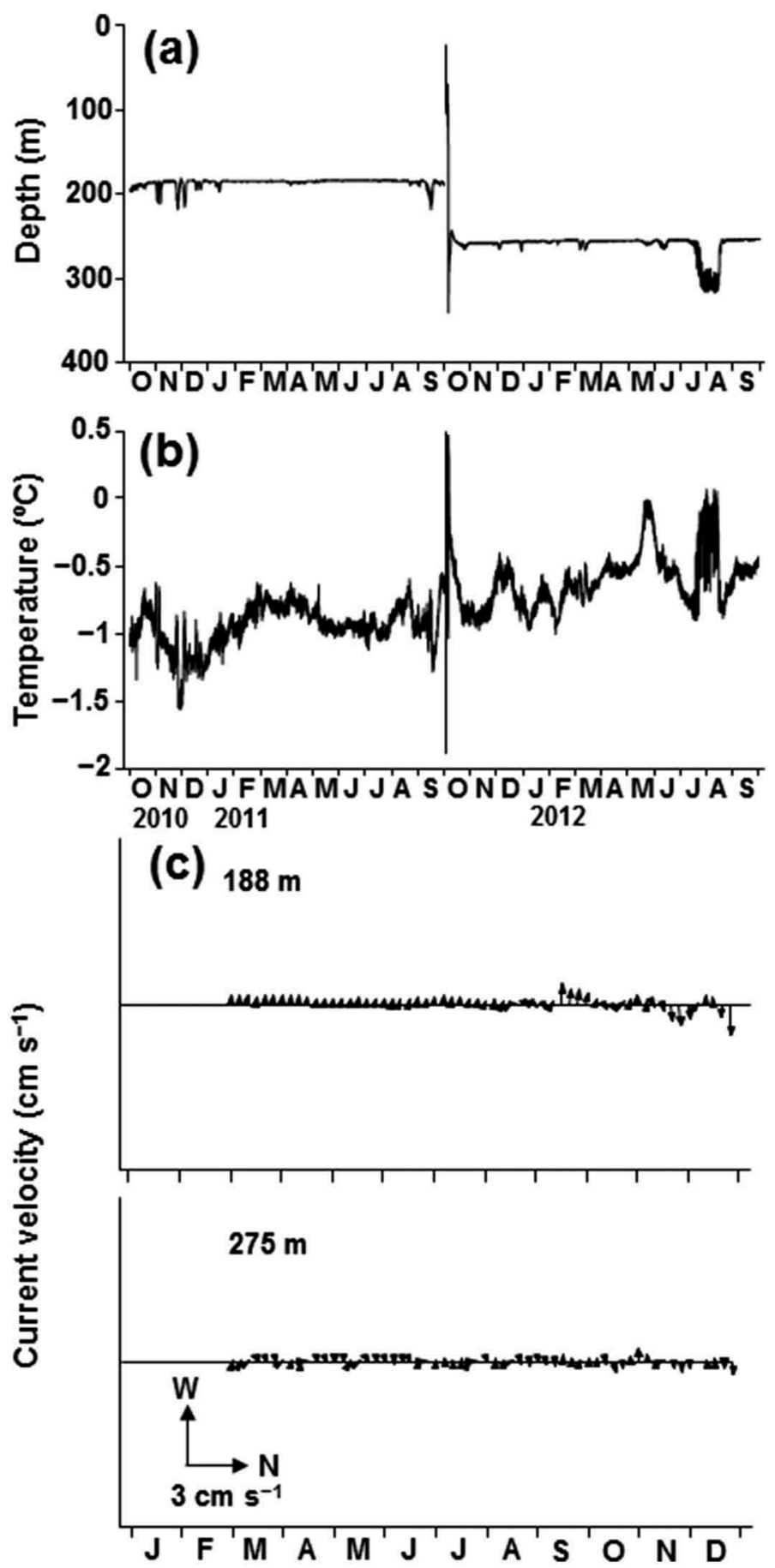

Figure 2. Seasonal changes in depth (a) and temperature (b) of the sediment trap at St. NAPt from October 2010 to September 2012. The current velocity at 188 and $275 \mathrm{~m}$ at St. NAPt (c) was estimated by a physical ocean general circulation model. 
(a)
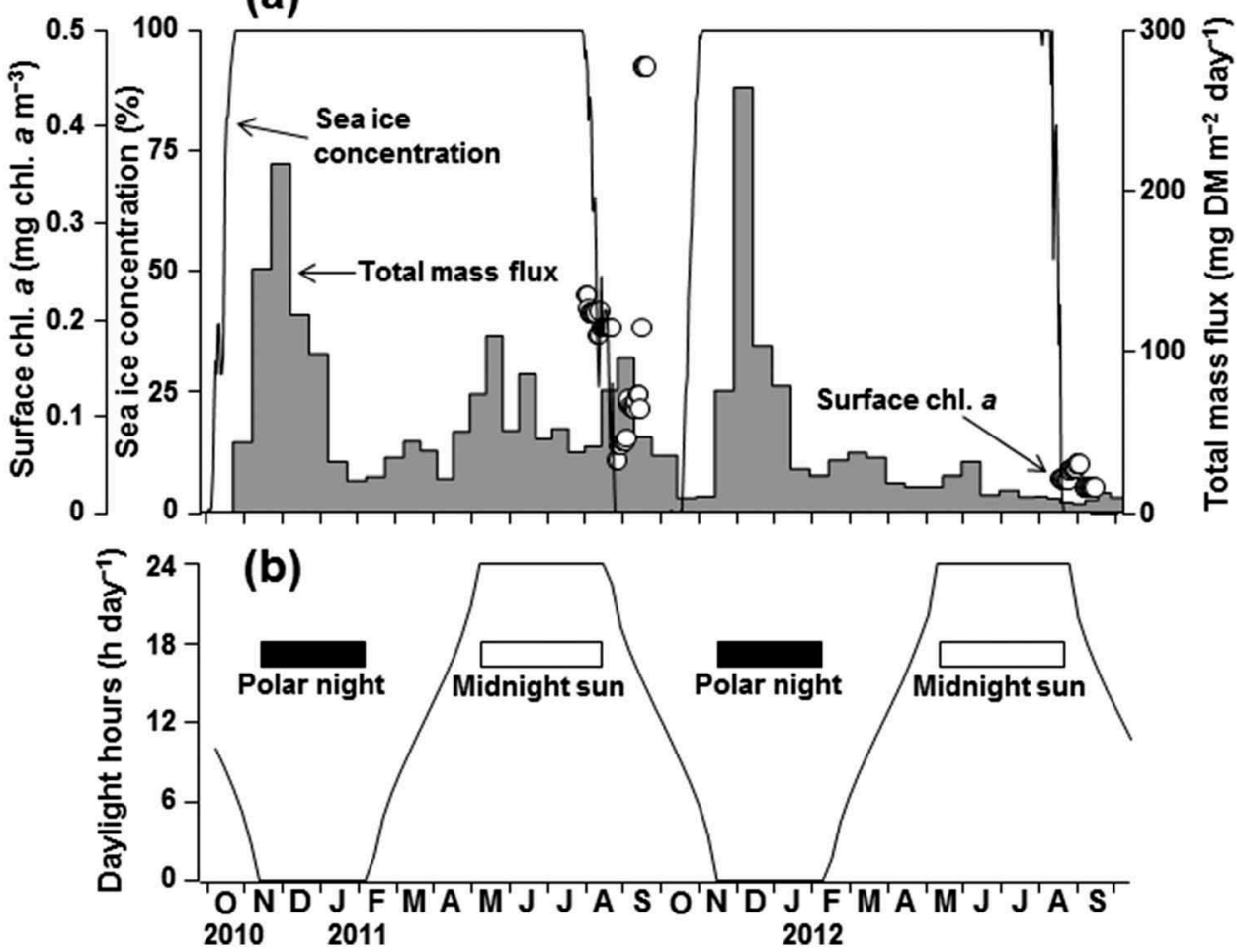

Figure 3. Seasonal changes in sea ice concentration, surface chl. $a$ (from satellite) and total mass flux (a), and daylight hours (b) at St. NAPt from October 2010 to September 2012.

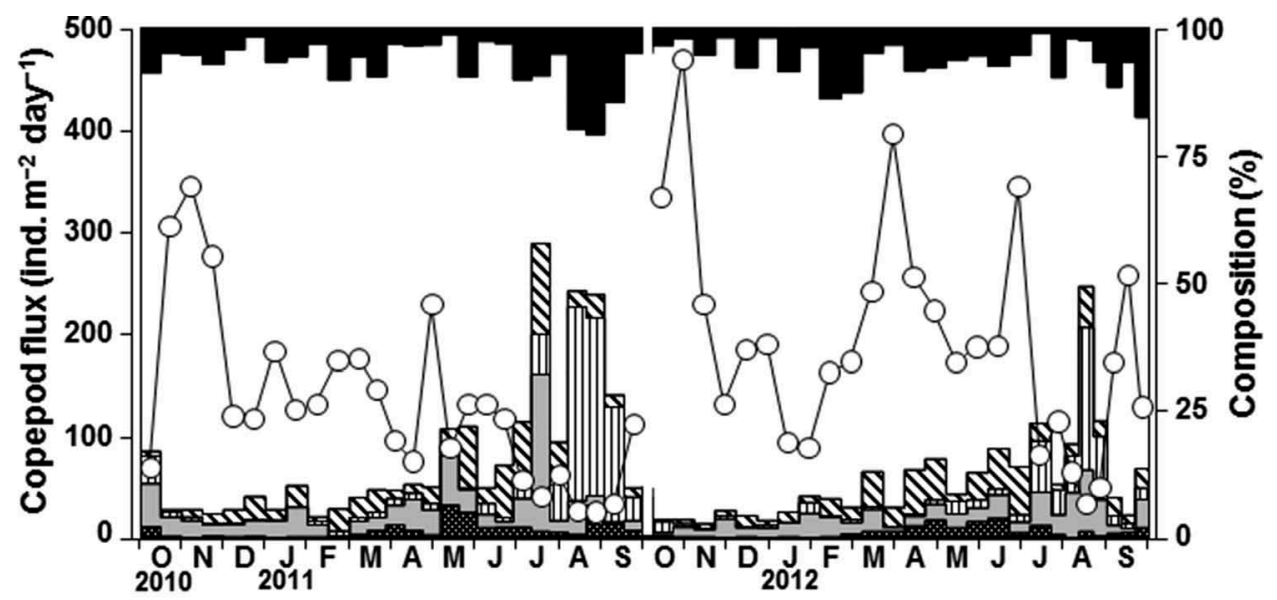

OFlux C. hyperboreus $\square M$. longa $\mathbb{m}$ 而 $P$. glacialis $\square H$. norvegicus O. parila Other species

Figure 4. Seasonal changes in the copepod flux and species composition at St. NAPt from October 2010 to September 2012. 
to April and October to November, and the early copepodid stages $(\mathrm{C} 1-\mathrm{C} 3)$ formed peaks two months earlier than the abundance peaks (Figure 5a). The abundance of $O$. parila was significantly correlated with the total mass flux from 2010 to 2011 (first year) $\left(p<0.05, r^{2}=0.164\right)$ (Figure 5b).

The abundance of $C$. hyperboreus peaked from March to June, and the population was dominated by C6F throughout the year (96\% of annual mean) (Figure 6a). For $M$. longa, abundance was slightly greater from April to May and October to November, and the population was dominated by C6F from January to June, and by early copepodid stages $(\mathrm{C} 1-\mathrm{C} 3)$ from September to January (Figure 6b). Paraeuchaeta glacialis had a distinct peak during July-October, and the early copepodid stages $(\mathrm{C} 1-\mathrm{C} 3)$ occurred from May to July (Figure 6c). Heterorhabdus norvegicus was the most abundant calanoid copepod, and its abundance peaked from April to June (Figure 6d). All copepodid stages of $H$. norvegicus were present and their abundant periods varied according to stage: $\mathrm{C} 1$ dominated from April to May, C5 dominated from November to February, and C6M dominated from August to October.

Lipid accumulation by $\mathrm{C6F}$ of $C$. hyperboreus was high (stage III) throughout the year (the annual mean was 50\%) (Figure 7a). Lipid accumulation of $M$. longa showed clear seasonality: it was high from October to February, after which lipids gradually decreased, reaching lowest levels in August (Figure 7b). For P. glacialis, high lipid individuals were abundant from February to April, after which lipid levels decreased gradually (Figure 7c).

Calanus hyperboreus showed distinct seasonality in gonad maturation of adult females: mature and spawning specimens were only observed from February to May (Figure 7d). For M. longa, mature and spawning specimens dominated from March to September (Figure 7e), and this reproductive period corresponded with the timing of low lipid accumulation (cf. Figure 7b). Most P. glacialis matured from October to November (Figure 7f).

\section{Discussion}

\section{Trap collection efficiency}

Detailed discussion on zooplankton collection efficiency of sediment traps in this region was published in Matsuno et al. (2014). Buesseler et al. (2007) had noted that the underestimation of flux contributed to shallow depths $(<1000 \mathrm{~m}$ depth) of a sediment trap might be due to the effect of restricted water flow. The flow rate around the trap of this study was slow $\left(1.2-2.7 \mathrm{~cm} \mathrm{~s}^{-1}\right)$ throughout the year (Figure 2c). Because of the slow flow rate, the effect of the current on the trap collection efficiency was thought to be limited. While the trap mooring depth varied between the first and second year (184-190 m versus 250-260 m), the mooring depth was constant during most of the sampling period, except in July 2012 (Figure 2a). This suggests that mooring conditions were stable throughout the period and that the collection efficiency of the trap seems to be acceptable.

Because most zooplankton collected by the sediment trap are swimmers, it is assumed the majority of the zooplankton community actively swam into the trap and were therefore killed by the preservation fluid in the cup (Knauer et al. 1979; Sampei et al. 2009). We counted dead individuals with a damaged or decomposed body but 


\section{(a) Oncaea parila}
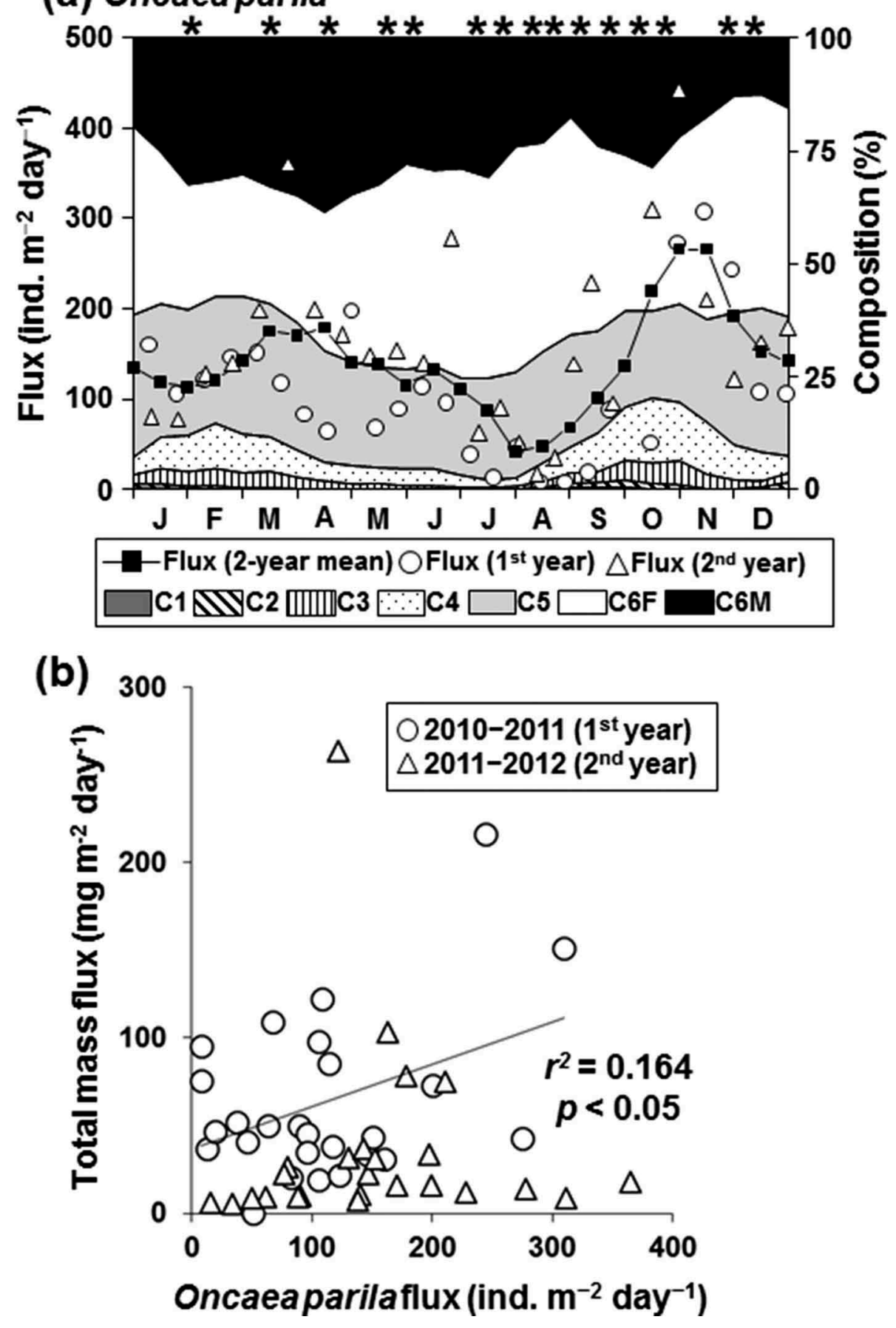

Figure 5. (a) Seasonal changes in the flux and copepodid stage composition of the dominant copepod Oncaea parila (Poecilostomatoida). ${ }^{*} \mathrm{C} 6 \mathrm{~F}$ with egg sacs occurred. (b) The relationship between O. parila flux and the total mass flux. A positive relationship was detected in 2010-2011 (first year). 
(a) C. hyperboreus

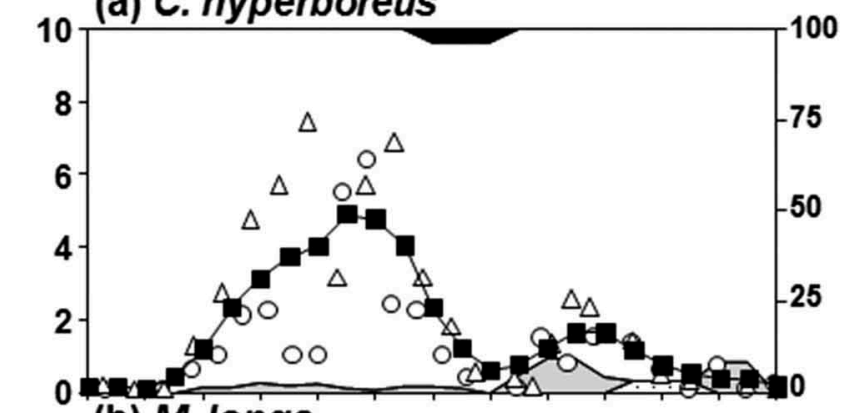

(b) M. longa

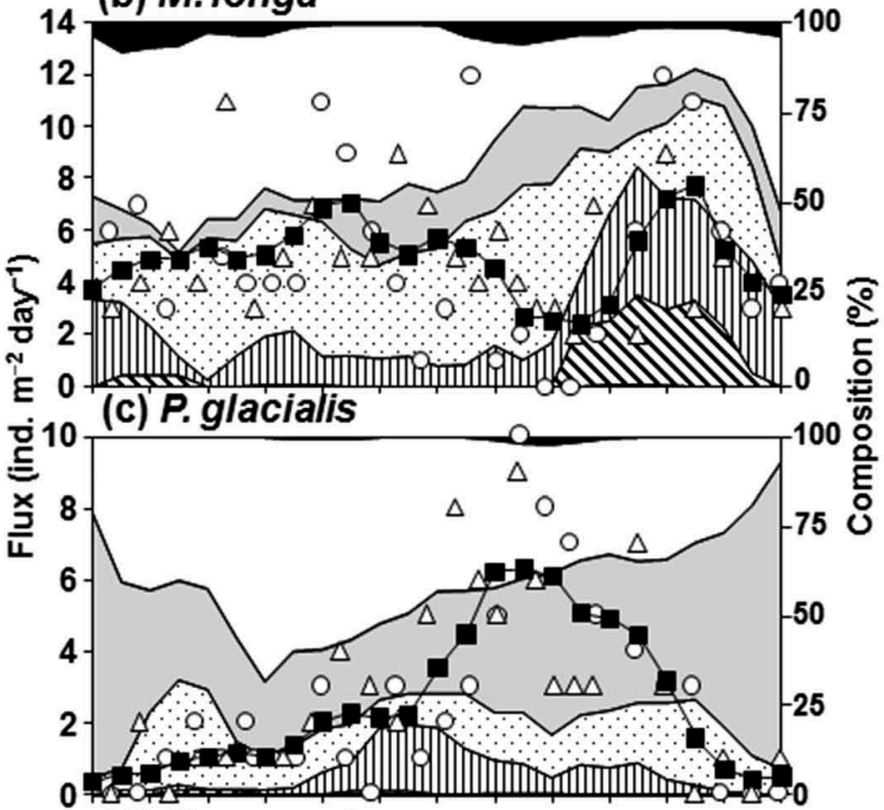

(d) $H$. norvegicus

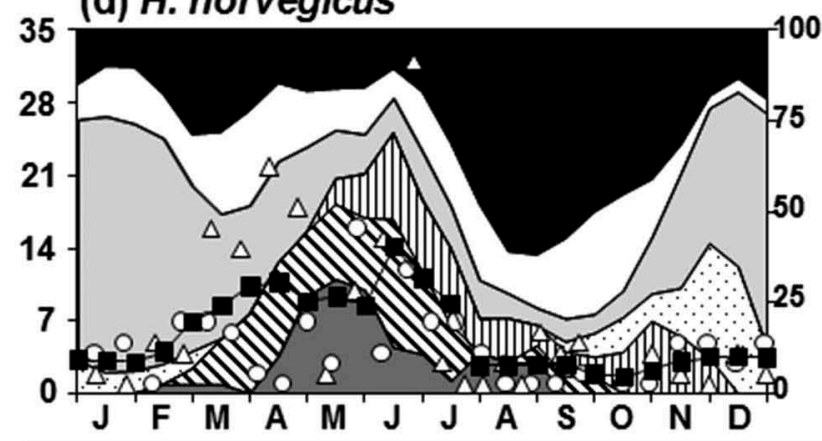

$\rightarrow-F l u x\left(2\right.$-year mean) $O F$ Flux (1 $1^{\text {st }}$ year) $\Delta$ Flux (2 $2^{\text {nd }}$ year $)$

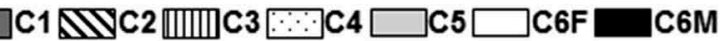

Figure 6. Seasonal changes in the flux and copepodid stage composition of the four large calanoid copepods: (a) Calanus hyperboreus; (b) Metridia longa; (c) Paraeuchaeta glacialis; and (d) Heterorhabdus norvegicus. 
(a) C. hyperboreus
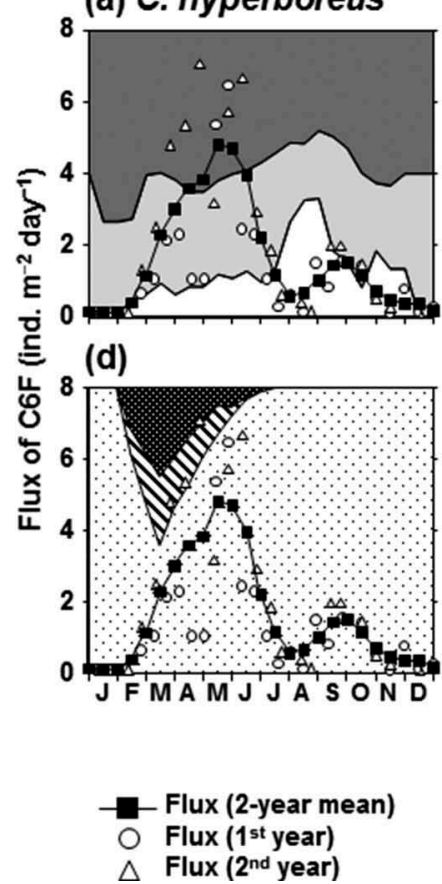

(b) M. longa

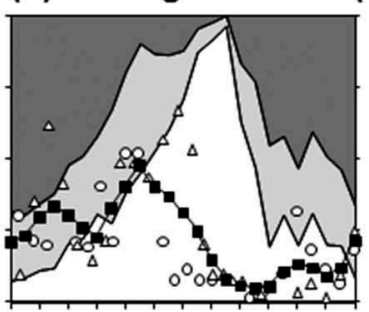

(e)

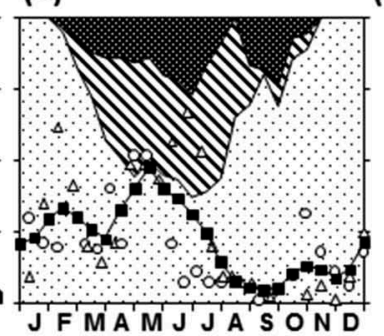

(f)

c) P. glacialis
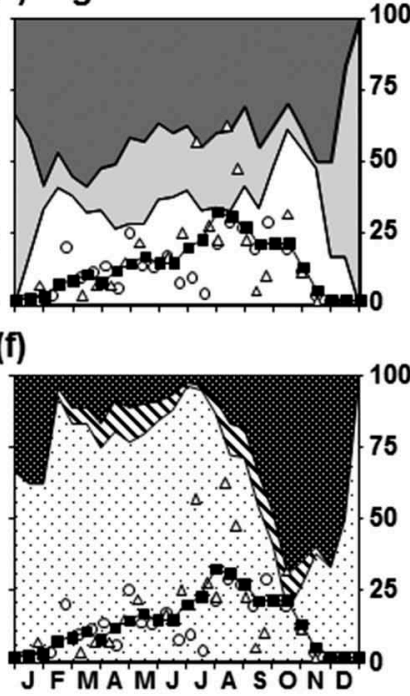

Gonad maturation (d-f)

Lipid accumulation (a-c)
$\square$ I $\square$ II $\square$ III

Figure 7. Seasonal changes in the flux of adult females, lipid accumulation (upper panels) and gonad maturation (lower panels) composition (stage I-III) of C6F (a, d) Calanus hyperboreus; (b, e) Metridia longa; and (c, f) Paraeuchaeta glacialis.

found their fraction was small $(<0.1 \%$ in abundance). Small zooplankton with poor swimming abilities (e.g. poecilostomatoid copepods) are thought to be attached to large detritus, such as marine snow, and are passively collected with the settlement of the detritus (Steinberg et al. 1998). The positive correlation between the abundance of $O$. parila and the total mass flux (Figure 5b) suggests that the poecilostomatoid copepods were passively collected with the settlement of the detritus.

On the other hand, calanoid copepods showed clear seasonal abundance patterns that varied by species. In all species, the seasonal abundance patterns were similar for both years (same seasonal repetition, cf. Figure 6). Because calanoid copepods actively swam into the trap, the abundant period of the calanoid copepods is thought to correspond with the period of the active vertical migration of each species. Clear seasonal changes were also observed for lipid accumulation and gonad maturation of calanoid copepods (Figure 7). These results suggest that sediment trap samples are suitable for the evaluation of the seasonal changes in the population structure of planktonic copepods in the Arctic Ocean.

\section{Seasonal abundance}

Seasonal changes in hydrographic parameters (sea ice concentration, daylight hours, sea surface chl. $a$ and total mass flux), copepod abundance peaks, and reproductive periods are summarized in Figure 8. 


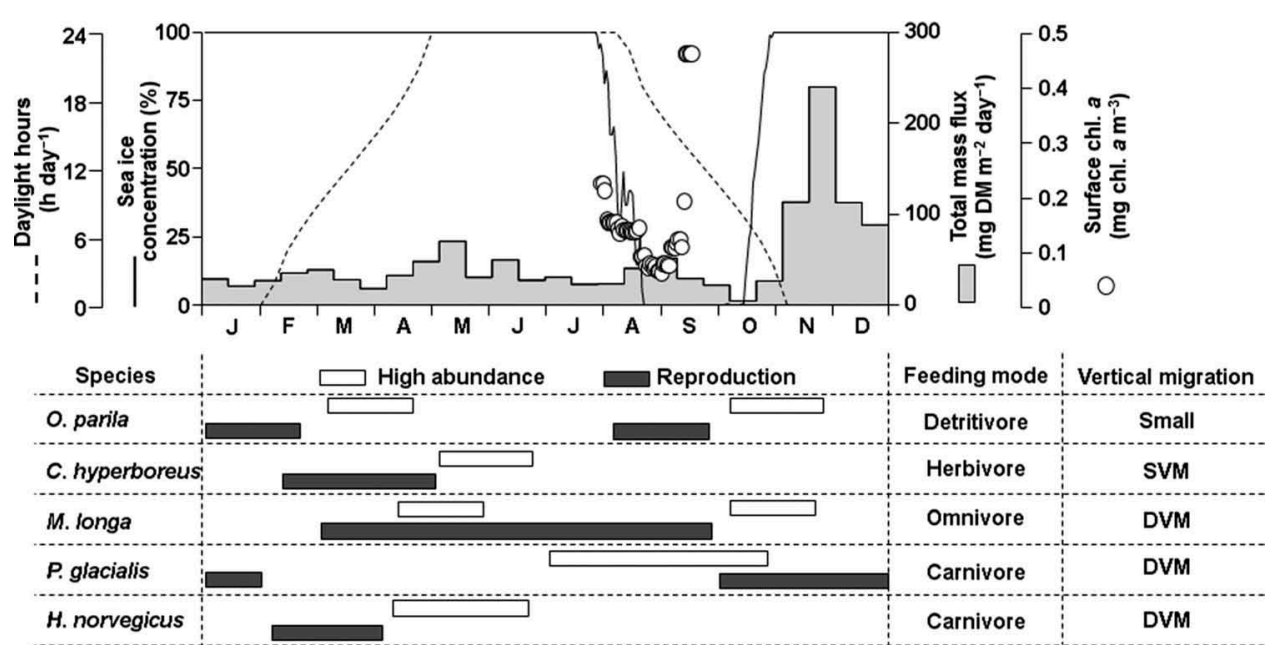

Figure 8. Seasonal changes in sea ice concentration, daylight hours, chl. $a$, and total mass flux from January to December (upper panel). The ecological characteristics of the five dominant copepods (lower panel). The open and solid bars indicate the high abundance and reproductive periods for each species, respectively.

Calanus hyperboreus perform seasonal vertical migration (SVM) (Vinogradov 1997). The abundant period (May-June) is interpreted as the timing of migration from deep water towards the surface (Vinogradov 1997). The lifespan of this species is typically three years, and reproduction occurs in the deep sea during the winter using stored lipids as the energy source (Falk-Petersen et al. 2009; Hirche 2013). The lipids accumulate in their body from grazing on phytoplankton at the surface during summer. Their upward migration to the surface layer enables them to graze on the ice algae and subsequent phytoplankton bloom (Forest et al. 2011), and this upward SVM is thought to occur from May to June in the western Arctic Ocean.

The other three calanoid copepods ( $M$. longa, P. glacialis and H. norvegicus) do not perform distinct SVM but have diel vertical migration (DVM) (Conover and Huntley 1991; Yamaguchi and Ikeda 2000; Kaartvedt et al. 2002). In high-latitude seas, the magnitude of the calanoid copepod DVM is reported to show seasonality: DVM is small in the winter and large when the diel changes in light intensity are highest (Falkenhaug et al. 1997). DVM is also known to cease during the polar night (Blachowiak-Samolyk et al. 2006). Considering these facts, the two abundance peaks of M. longa from April to May and October to November are interpreted as the DVM activity of this species during seasons with clearly contrasting day-night light intensities.

The abundant period of $P$. glacialis (July-October) corresponded with the period of high day-night contrast in light intensity in the open water season, whereas no peak was observed in that of the ice-covered season (February-April). Paraeuchaeta glacialis is a carnivore and preys upon small copepods (e.g. Pseudocalanus spp.) (Auel and Hagen 2005). This suggests that the intensity of DVM of this species is greater during open water season when their prey, small-sized copepods, are abundant.

The other carnivore, $H$. norvegicus, had an abundance peak from April to June during the period of greatly contrasting day-night light intensities in the ice-covered 
season (Figure 8). Heterorhabdus species is known to have a labral-gland pore on the ventralmost mandibular tooth that can inject venom or anaesthetic, and it preys upon macrozooplankton such as copepods and polychaetes (Nishida and Ohtsuka 1996). In contrast, Paraeuchaeta spp. is known to be a cruising predator (Greene and Landry 1985). These differences in the feeding modes of the carnivorous copepods may be reflected by the differences in active DVM seasons (April-June for $H$. norvegicus, and July-October for P. glacialis).

\section{Reproductive period}

The year-round occurrence of $O$. parila adult females carrying egg sacs suggests that reproduction occurred throughout the year with two peaks, January-February and August-September. The early copepodid stages $(\mathrm{C} 1-\mathrm{C} 3)$ also showed two peaks (Figure 5a). Oncaea parila is typically distributed at a depth of 500-1000 m, and adults dominate the population ( $>50 \%$ of the total) throughout the year in the Oyashio region of the subarctic Pacific (Nishibe and Ikeda 2007). Shallower occurrences of this species are observed in the Arctic Ocean $(184-260 \mathrm{~m})$ than in the Oyashio region and may correlate with the lower temperature $\left(-1.9-0.5^{\circ} \mathrm{C}\right)$ of the Arctic Ocean. The dominance of this species of poecilostomatoid copepods is reported in both the Arctic and Antarctic Oceans (Heron et al. 1984; Metz 1996). However, evaluation of the life cycle of this species is difficult from this data set.

The particle-feeding copepod $C$. hyperboreus grazes on phytoplankton, stores lipid in an oil sac while at the surface layer, and then matures and reproduces in deeper waters (Falk-Petersen et al. 2009; Hirche 2013). The reproductive season of this species is reported to occur from November to April in the Amundsen Gulf $\left(70^{\circ} 38^{\prime}-71^{\circ} 32^{\prime} \mathrm{N}\right)$ (Ota et al. 2008), from November to March in the Greenland Sea $\left(74^{\circ} 06^{\prime}-77^{\circ} 45^{\prime} \mathrm{N}\right)$ (Hirche and Niehoff 1996), and from February to March in the Norwegian Sea $\left(66^{\circ} 00^{\prime} \mathrm{N}\right)$ (Østvedt 1955). The observed reproductive timing (February-May) in the western Arctic Ocean $\left(75^{\circ} 00^{\prime} \mathrm{N}\right)$ in this study is during the ice-covered season, which is consistent with the findings of previous studies, although the onset and offset timings were later than in the other areas. The reproductive timing of this species is known to be greatly affected by the timing of the phytoplankton bloom (Hirche and Niehoff 1996; Falk-Petersen et al. 2009). The late reproductive timing observed in this study may be a reflection of the differences in the phytoplankton bloom period in this region. The onset of the phytoplankton bloom (mostly the ice-edge bloom) occurred from April to June in other areas (Daase et al. 2013), whereas the onset of the bloom in the western Arctic Ocean occurred in late July (Figure 8).

The particle-feeder M. long a accumulated lipids from October to February, and reproduced from March to September in the western Arctic Ocean (Figure 7b and e). The reproductive season of this species varies greatly in different regions, i.e. occurring from April to May in Balsfjorden (Tande and Grønvik 1983), in the autumn at the polynya of the Beaufort Sea (Makabe et al. 2010), and in the winter under the sea ice in the Barents Sea (Hirche and Kosobokova 2011). The reproductive period in the western Arctic Ocean as observed in this study (March -September) was much longer than that of these other regions. Phytoplankton and various other organisms (e.g. ciliates and the eggs of $C$. hyperboreus) are reported 
as the food sources of this species (Båmstedt and Ervik 1984; Sell et al. 2001). Since the western Arctic Ocean is composed mostly of the highly productive Chukchi Sea, the flexibility of $M$. longa to prey upon a variety of food sources may contribute to their long reproductive period.

Compared with the other species examined in this study, little information is available on the life cycles of the two carnivorous copepods ( $P$. glacialis and $H$. norvegicus) in the Arctic Ocean. From the present results, reproduction of $P$. glacialis and $H$. norvegicus is thought to occur from October-January and February-May, respectively (Figure 8). Thus, the reproductive timings of the two sympatric carnivorous copepods are non-overlapping (Figure 8). The seasonality of these two carnivores also explains the abundance patterns mentioned above. Similarly, the species-specific reproduction timing may reflect the differences in the feeding modes of these species, as the food items utilized by these two species vary greatly (Greene and Landry 1985; Nishida and Ohtsuka 1996). As primary production and phenology in the Arctic Ocean shows clear seasonality, the seasons when small copepods and macrozooplankton are abundant are likely to be different. These differences in the seasonal occurrence of food items may result in differences in the reproductive timings of the two sympatric carnivorous species.

In conclusion, seasonal changes in the population structures of five dominant planktonic copepods in the Arctic Ocean were evaluated. Because the sediment trap was moored at a fixed depth, the results of the collected zooplankton community were subject to an inevitable bias. Despite this shortcoming, evaluation of the life cycles of planktonic copepods by using a sediment trap should be considered a powerful tool in the polar seas where seasonal sampling with a plankton net is difficult.

\section{Acknowledgements}

We are grateful to the captain, officers, and crews of the R.V. Mirai (JAMSTEC), operated by GODI, R/V CCGS Sir Wilfrid Laurier, and Dr Humfrey Melling (IOS, Canada) for their help in the mooring operation and sample collection.

\section{Disclosure statement}

No potential conflict of interest was reported by the author(s).

\section{Funding}

This study was supported by the Green Network of Excellence Program (GRENE Program), the Arctic Climate Change Research Project 'Rapid Change of the Arctic Climate System and its Global Influences', and the Grant-in-Aid for Scientific Research [(S) 22221003 Catastrophic reduction of sea-ice in the Arctic Ocean - its impact on the marine ecosystems in the polar region] to NH. Part of this study was supported by the Grant-in-Aid for Scientific Research [(A) 24248032] and the Grant-in-Aid for Scientific Research on Innovative Areas [24110005] from the JSPS.

\section{References}

Ashjian CJ, Campbell RG, Welch HE, Butler M, Keuren DV. 2003. Annual cycle in abundance, distribution, and size in relation to hydrography of important copepod species in the western Arctic Ocean. Deep-Sea Res I. 50:1235-1261. 
Auel H, Hagen W. 2005. Body mass and lipid dynamics of Arctic and Antarctic deep-sea copepods (Calanoida, Paraeuchaeta): ontogenetic and seasonal trends. Deep-Sea Res I. 52:1272-1283.

Båmstedt U, Ervik A. 1984. Local variations in size and activity among Calanus finmarchicus and Metridia longa (Copepoda, Calanoida) overwintering on the west coast of Norway. J Plankton Res. 6:843-857.

Blachowiak-Samolyk K, Kwasniewski S, Richardson K, Dmoch K, Hansen E, Hop H, FalkPetersen S, Mouritsen LT. 2006. Arctic zooplankton do not perform diel vertical migration (DVM) during periods of midnight sun. Mar Ecol Prog Ser. 308:101-116.

Brodsky KA. 1967. Calanoida of the Far-eastern Seas and Polar Basin of the USSR. Jerusalem: Israel Program Scientific Translation.

Buesseler KO, Antia AN, Chen M, Fowler SW, Gardner WD, Gustafsson O, Harada K, Michaels AF, van der Loeff MR, Sarin M, et al. 2007. An assessment of the use of sediment traps for estimating upper ocean particle fluxes. J Mar Res. 65:345-416.

Conover RJ, Huntley M. 1991. Copepods in ice-covered seas - distribution, adaptations to seasonally limited food, metabolism, growth patterns and life cycle strategies in polar seas. J Mar Syst. 2:1-41.

Daase M, Falk-Petersen S, Varpe Ø, Darnis G, Søreide JE, Wold A, Leu E, Berge J, Philippe B, Fortier L. 2013. Timing of reproductive events in the marine copepod Calanus glacialis: a pan-Arctic perspective. Can J Fish Aquat Sci. 70:871-884.

Falk-Petersen S, Mayzaud P, Kattner G, Sargent JR. 2009. Lipids and life strategy of Arctic Calanus. Mar Biol Res. 5:18-39.

Falkenhaug T, Tande KS, Semenova T. 1997. Diel, seasonal and ontogenetic variations in the vertical distributions of four marine copepods. Mar Ecol Prog Ser. 149:105-119.

Forbes JR, Macdonald RW, Carmack EC, Iseki K, O'Brien MC. 1992. Zooplankton retained in sequential sediment traps along the Beaufort Sea shelf break during winter. Can J Fish Aquat Sci. 49:663-670.

Forest A, Galindo V, Darnis G, Pineault S, Lalande C, Tremblay J-E, Fortier L. 2011. Carbon biomass, elemental rations $(\mathrm{C}: \mathrm{N})$ and isotopic composition $\left(\delta^{13} \mathrm{C}, \delta^{15} \mathrm{~N}\right)$ of dominant calanoid copepods during the winter-to-summer transition in the Amundsen Gulf (Arctic Ocean). J Plankton Res. 33:161-178.

Frost BW. 1974. Calanus marshallae, a new species of calanoid copepod closely allied to the sibling species C. finmarchicus and C. glacialis. Mar Biol. 26:77-99.

Frost BW. 1989. A taxonomy of the marine calanoid copepod genus Pseudocalanus. Can J Zool. 67:525-551.

Greene CH, Landry MR. 1985. Patterns of prey selection in the cruising calanoid predator Euchaeta elongata. Ecology. 66:1408-1416.

Hargrave BT, von Bodungen B, Conover RJ, Fraser AJ, Phillips G, Vass WP. 1989. Seasonal changes in sedimentation of particulate matter and lipid content of zooplankton collected by sediment trap in the Arctic Ocean off Axel Heiberg Island. Polar Biol. 9:467-475.

Heron GA, English TS, Damkaer DM. 1984. Arctic Ocean Copepoda of the genera Lubbockia, Oncaea, and Epicalymma (Poecilostomatoida: Oncaeidae), with remarks on distributions. J Crust Biol. 4:448-490.

Hirche H-J. 2013. Long-term experiments on lifespan, reproductive activity and timing of reproduction in the Arctic copepod Calanus hyperboreus. Mar Biol. 160:2469-2481.

Hirche HJ, Kosobokova KN. 2011. Winter studies on zooplankton in Arctic seas: the Storfjord (Svalbard) and adjacent ice-covered Barents Sea. Mar Biol. 158:2359-2376.

Hirche H-J, Niehoff B. 1996. Reproduction of the Arctic copepod Calanus hyperboreus in the Greenland sea-field and laboratory observations. Polar Biol. 16:209-219.

Kaartvedt S, Dale T, Bagøien E, Viken T. 2002. Bi-modal vertical distribution of the carnivorous copepod Paraeuchaeta norvegica. J Plankton Res. 24:155-158. 
Knauer G, Martin JH, Bruland KW. 1979. Fluxes of particulate carbon, nitrogen, and phosphorus in the upper water column of the northeast Pacific. Deep-Sea Res. 26:97-108.

Kosobokova KN, Hirche H-J, Hopcroft RR. 2007. Reproductive biology of deep-water calanoid copepods from the Arctic Ocean. Mar Biol. 151:919-934.

Lowry LF, Sheffield G, George C. 2004. Bowhead whale feeding in the Alaskan Beaufort Sea, based on stomach contents analyses. J Cetacean Res Manage. 6:215-223.

Makabe R, Hattori H, Sampei M, Ota Y, Fukuchi M, Fortier L, Sasaki H. 2010. Regional and seasonal variability of zooplankton collected using sediment traps in the southeastern Beaufort Sea, Canadian Arctic. Polar Biol. 33:257-270.

Matsuno K, Yamaguchi A, Fujiwara A, Onodera J, Watanabe E, Imai I, Chiba S, Harada N, Kikuchi T. 2014. Seasonal changes in mesozooplankton swimmers collected by sediment trap moored at a single station on the Northwind Abyssal Plain in the western Arctic Ocean. J Plankton Res. 36:490-502.

Metz C. 1996. Life strategies of dominant Antarctic Oithonidae (Cyclopoida, Copepoda) and Oncaeidae (Poecilostomatoida, Copepoda) in the Bellingshausen Sea (in German with English abstract). Ber Polarforsch. 207:1-123.

Miller CB. 1988. Neocalanus flemingeri, a new species of Calanidae (Copepoda: Calanoida) from the subarctic Pacific Ocean, with a comparative redescription of Neocalanus plumchrus (Marukawa) 1921. Prog Oceanog. 20:223-273.

Nishibe Y, Ikeda T. 2007. Vertical distribution, population structure and life cycles of four oncaeid copepods in the Oyashio region, western subarctic Pacific. Mar Biol. 150:609 -625 .

Nishida S, Ohtsuka S. 1996. Specialized feeding mechanism in the pelagic copepod genus Heterorhabdus (Calanoida: Heterorhabdidae), with special reference to the mandibular tooth and labral glands. Mar Biol. 126:619-632.

Østvedt OJ. 1955. Zooplankton investigations from weathership " $M$ " in the Norwegian Sea, 1948-49. Hvalrad Skr. 40:1-93.

Ota Y, Hattori H, Makabe R, Sampei M, Tanimura A, Sasaki H. 2008. Seasonal changes in nauplii and adults of Calanus hyperboreus (Copepoda) captured in sediment traps, Amundsen Gulf, Canadian Arctic. Polar Sci. 2:215-222.

Reynolds RW, Rayner NA, Smith TM, Stokes DC, Wang W. 2002. An improved in situ and satellite SST analysis for climate. J Climate. 15:1609-1625.

Sampei M, Sasaki H, Hattori H, Forest A, Fortier L. 2009. Significant contribution of passively sinking copepods to the downward export flux in Arctic waters. Limnol Oceanogr. 54:1894-1900.

Sell AF, van Keuren D, Madin LP. 2001. Predation by omnivorous copepods on early developmental stages of Calanus finmarchicus and Pseudocalanus spp. Limnol Oceanogr. 46:953-959.

Steinberg DK, Pilskaln CH, Silver MW. 1998. Contribution of zooplankton associated with detritus to sediment trap 'swimmer' carbon in Monterey Bay, California, USA. Mar Ecol Prog Ser. 164:157-166.

Tande KS, Grønvik S. 1983. Ecological investigations on the zooplankton community of Balsfjorden, northern Norway: sex ratio and gonad maturation cycle in the copepod Metridia longa (Lubbock). J Exp Mar Biol Ecol. 71:43-54.

Vinogradov ME. 1997. Some problems of vertical distribution of meso- macroplankton in the ocean. Adv Mar Biol. 32:1-92.

Wassmann P, Reigstad M, Haug T, Rudels B, Carroll ML, Hop H, Gabrielsen GW, FalkPetersen S, Denisenko SG, Arashkevich E, et al. 2006. Food webs and carbon flux in the Barents Sea. Prog Oceanogr. 71:232-287.

Watanabe E, Onodera J, Harada N, Honda MC, Kimoto K, Kikuchi T, Nishino S, Matsuno $\mathrm{K}$, Yamaguchi A, Ishida A, et al. 2014. Enhanced role of eddies in the Arctic marine biological pump. Nat Commun. 5:3950. 


\section{K. Matsuno et al.}

Willis KJ, Cottier FR, Kwaśniewski S. 2008. Impact of warm water advection on the winter zooplankton community in an Arctic fjord. Polar Biol. 31:475-481.

Willis KJ, Cottier FR, Kwaśniewski S, Wold A, Falk-Petersen S. 2006. The influence of advection on zooplankton community composition in an Arctic fjord (Kongsfjorden, Svalbard). J Mar Syst. 61:39-54.

Yamaguchi A, Ikeda T. 2000. Vertical distribution, life cycle, and body allometry of two oceanic calanoid copepods (Pleuromamma scutullata and Heterorhabdus tanneri) in the Oyashio region, western North Pacific Ocean. J Plankton Res. 22:29-46. 